\title{
CONFLICT AND CONTROL:
}

LAW AND ORDER IN NINETEENTHCENTURY ITALY 


\section{CONFLICT AND CONTROL: LAW AND ORDER IN NINETEENTH- CENTURY ITALY}

John A. Davis

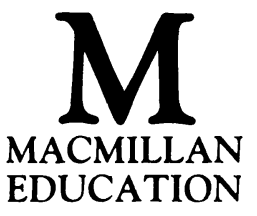


(C) John A. Davis 1988

All rights reserved. No reproduction, copy or transmission of this publication may be made without written permission.

No paragraph of this publication may be reproduced, copied or transmitted save with written permission or in accordance with the provisions of the Copyright Act 1956 (as amended), or under the terms of any licence permitting limited copying issued by the Copyright Licensing Agency, 33-4 Alfred Place, London WC1E 7DP.

Any person who does any unauthorised act in relation to this publication may be liable to criminal prosecution and civil claims for damages.

First published 1988

Published by

MACMILLAN EDUCATION LTD

Houndmills, Basingstoke, Hampshire RG21 2XS

and London

Companies and representatives

throughout the world

Typeset by Wessex Typesetters

(Division of The Eastern Press Ltd)

Frome, Somerset

British Library Cataloguing in Publication Data

Davis, John A. (John Anthony)

Conflict and control: law and order in

nineteenth-century Italy.

1. Offenses against public safety-

Italy-History - 19th century

I. Title

363.3'0945 HV6989

ISBN 978-0-333-28648-7

DOI 10.1007/978-1-349-19277-9 


\section{Contents}

Dedication vi

Acknowledgements vii

Maps ix

Introduction: Law and Order in a Changing World: Italy 1790-1900

PART I: The Passing of the Old Order

1 The Crisis of the Old Order 17

2 Communities in Conflict 38

3 Beggars, Brigands and Bandits 66

4 Urban Order and Disorder 91

5 Law and Public Order after the Restoration 120

PART II: The Making of the New Order

6 From Revolution to Civil War: the Making of the Liberal Order

7 Political Dissent and Social Unrest in Liberal Italy 187

8 The Police and the People in Liberal Italy 1860-90 211

9 The Guardians of the Law 242

10 Public Order and Private Order 262

11 Crime and the Southern Question: Mafiosi and Camorristi 290

12 'Italy's Sad Primacy': Crime and the Social Question 314

Epilogue: The Crisis of the 1890s - An Open Verdict 343

Abbreviations $\quad 360$

Notes $\quad 362$

Index $\quad 389$ 
For my Parents 


\section{Acknowledgements}

As well as researches and interests of my own, this book reflects the work of many Italian historians, and particularly those who in recent years have begun to explore Italy's social and economic history in the 19th century. Even a cursory glance at the end-notes will indicate the extent of my indebtedness to their work and I hope that in transposing ideas and arguments from the contexts in which they were first developed I have not unduly distorted them. If this book contributes to widening the interest in the challenging and stimulating historical research and debates that are currently in progress on these issues in Italy, at least one of its author's ambitions will be realised.

In writing this book I have received support and encouragement from friends and colleagues both here and in Italy who are unfortunately too numerous to name. I must record my gratitude to the University of Warwick, however, for allowing me study leave, and to the President and Faculty of the European University Institute at Florence, who granted me a Jean Monnet Fellowship in 1984-85 when the research for this book was completed, and where Stuart Woolf and the members of his seminar provided me with innumerable opportunities to test and develop themes and ideas. My wife and daughters have withstood the considerable disorders that the writing of this book has imposed on our family life, and have always been an unfailing source of support and assistance. I owe very particular debts of gratitude to Adrian Lyttelton, Denis Mack Smith and Stuart Woolf who generously gave their time to read and comment on the manuscript of this book. Their suggestions have been extremely valuable, and have also saved me from many foolish errors. Those that remain are all my own work, for which I take full responsibility.

John A. Davis

February 1987

The author and publishers wish to thank the following who have kindly given permission for the use of copyright material:

Unwin Hyman Ltd for extracts from W. Nassau Senior Journals Kept in France and Italy 1848-52, (1973), Vol. I.

Every effort has been made to trace all the copyright holders but if any have been inadvertently overlooked the publishers will be pleased to make the necessary arrangement at the first opportunity. 


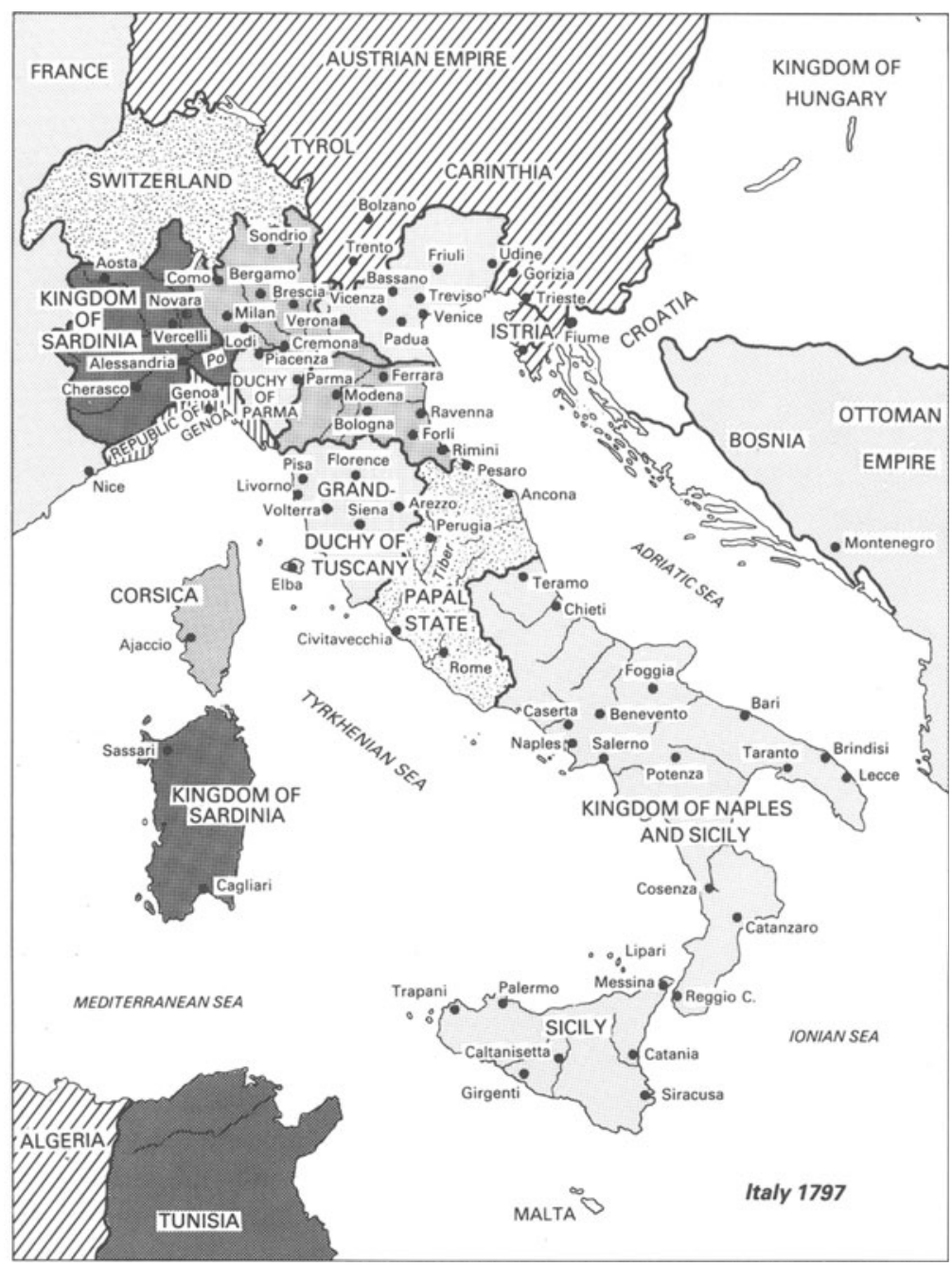




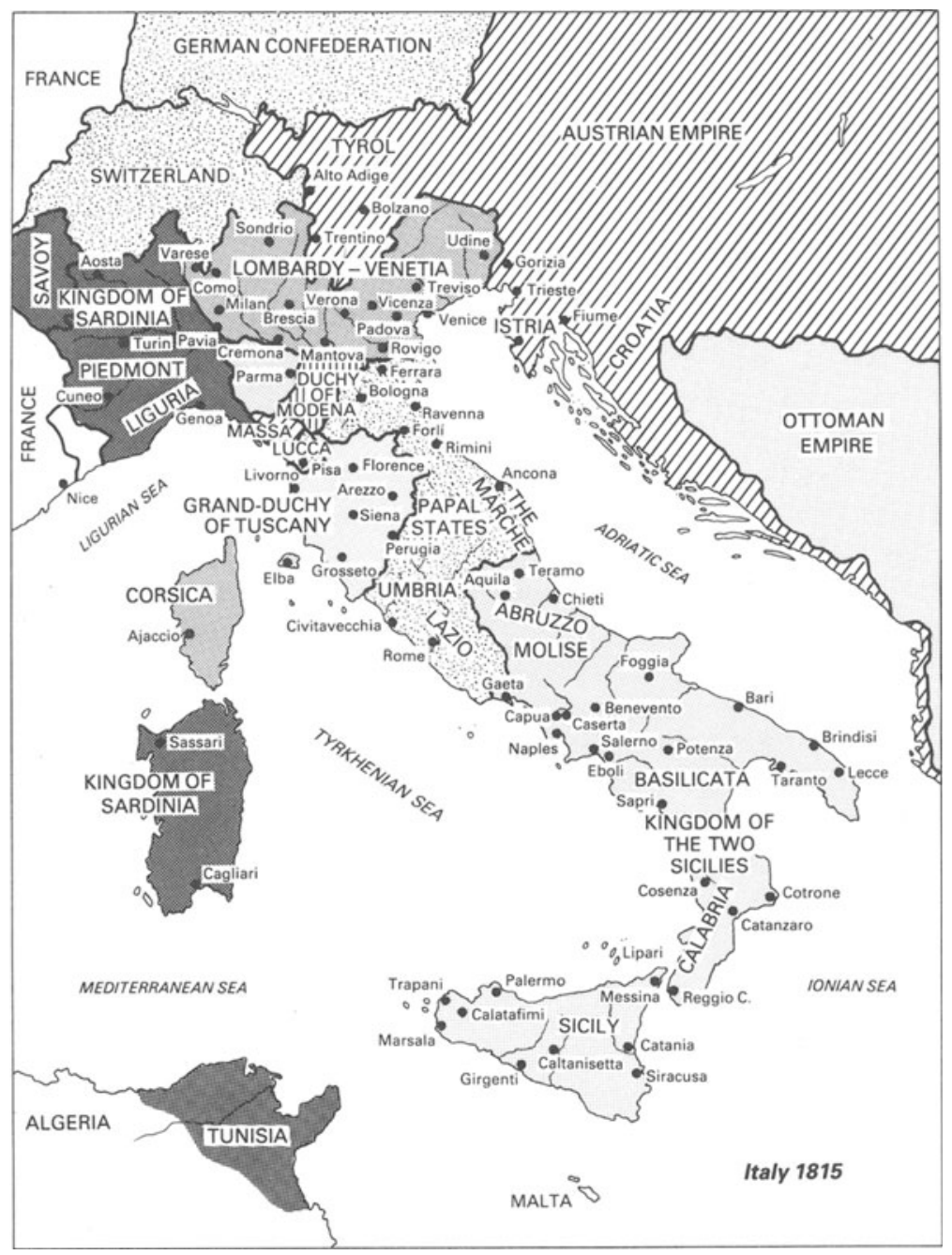




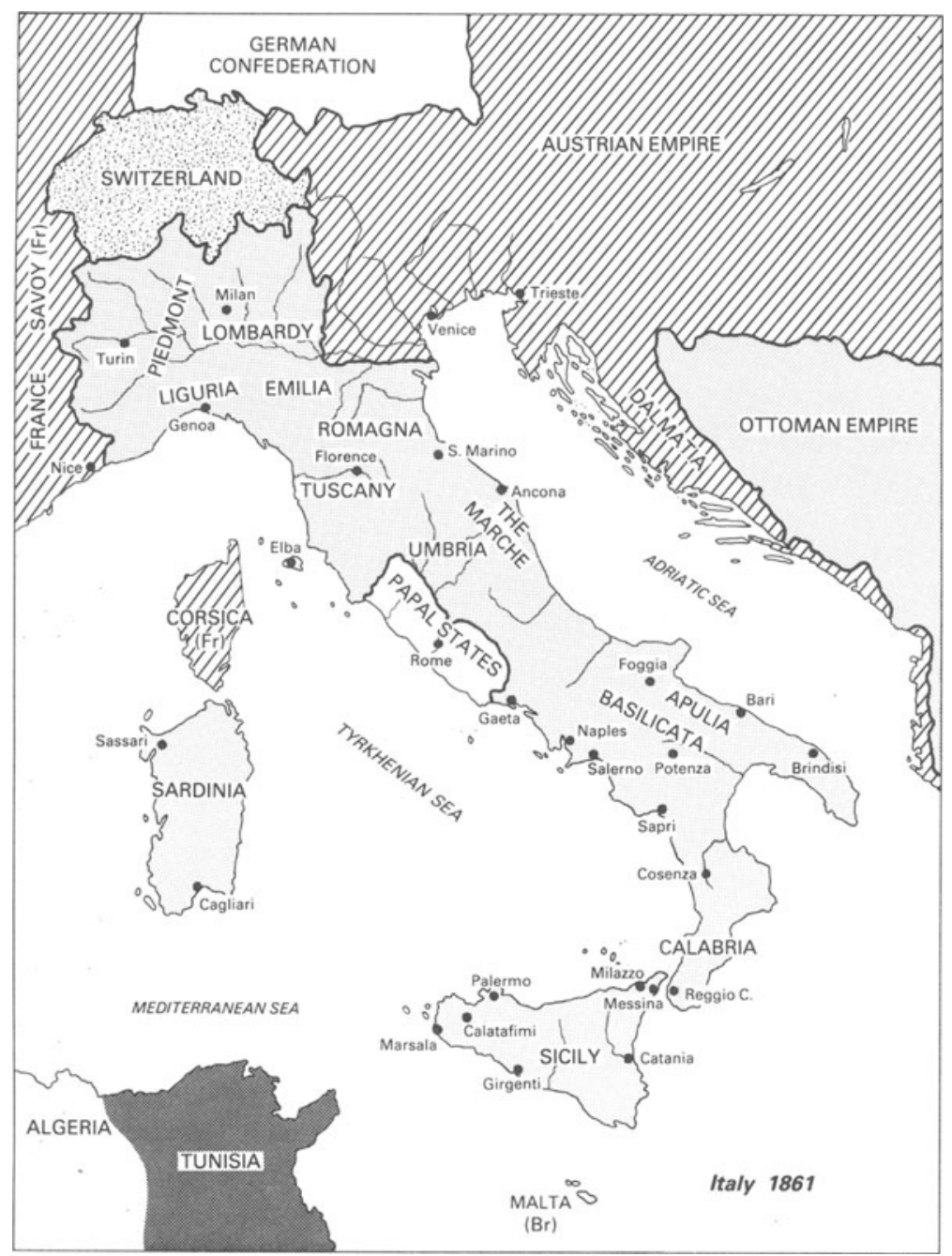




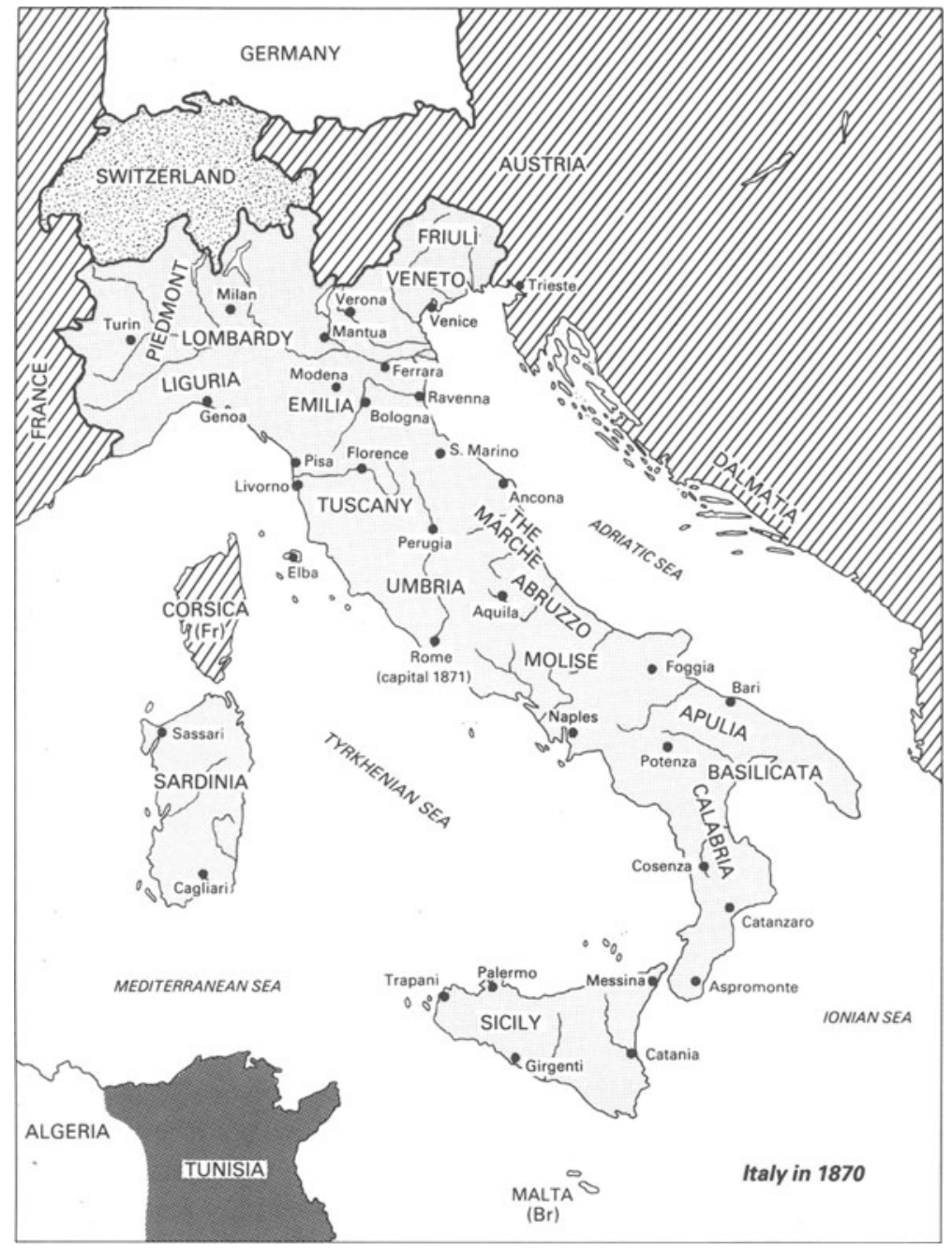

